\title{
Discussion on Fukuzawa Yukichi's Civilization Concept and Independent Practical Leaning Thought
}

\author{
Hao Tang \\ The School of Japanese Studies \\ Dalian University of Foreign Languages \\ Dalian, China
}

\begin{abstract}
The Meiji period was an important period of Japanese society transformation. It was an important historical turning point for Japan. Fukuzawa Yukichi was one of the indelible traces of this period. As a witness, he witnessed the country step by step process toward the modernization after the incident of "Wang Zheng Retro", as an ideological pioneer, he made modern civilization concept take root in Japan's land, he promoted "independence" and "practical learning" and made the concept of civilized civilization deeply rooted in people's minds, and he used his active actions to prompt the Japanese nationals toward to the goal of the coordinated development of morality and mentality. "Civilization", "Independence" and "Practical Learning" are the core of Fukuzawa's thoughts. This article will discuss the impact of his thoughts and the enlightenment left to us through the analysis of his concept of civilization and independent practical learning thought.
\end{abstract}

Keywords-Fukuzawa Yukichi; concept of civilization; independence; practical learning

\section{INTRODUCTION}

Yukichi Fukuzawa was one of the great thinkers in Japanese history. He has unique and profound views on the development of the country and the trend of the times. His views and opinions still have a high degree of social value and reference value. In recent years, most of the domestic studies on the philosophy of Fukuzawa Yukichi are based on two perspectives; one is compare study perspective and the frequent topics such as the contrast between Liang Qichao and Yukichi Fukuzawa's thoughts, the contrast between Yan Fu and Fukuzawa's western views. The second is the perspective of historical research; the research in this area mainly focuses on the promotion process of the Meiji Restoration and is based on the background of the era. On the basis of summarizing the results of previous researches, this article reads a large number of representative works and related books, and analyzes the nature of his thoughts based on its theoretical concepts and its works.

\section{REFERENCE AND TRANSFORMATION, RESHAPING ITS OWN CIVILIZATION}

\section{A. The Road of "Rangaku"}

FukuzawaYukichi was born in a Fan Shi family in low status, his father Fukuzawa Yukichi is a famous Chinese scholar with a high reputation. When he was young, he was not given the opportunity to attend school because of family poverty. Until very late, he had the opportunity to enroll in school and learn "Sinology" in his private school. In the process of Fukuzawa Yukichi's step-by-step growth, his understanding of the people's ignorance became clearer. He couldn't understand why the people feared the ethereal spirit and could not understand why the people did not rebel against the feudal system that oppressed them everyday. In the process of learning "Sinology", he began to discover that the deepest part of Sinology had a close bondage with the feudal concept and the feudal system. This disappointed him and he became more eager to stay away from the feudal dominant family system, so he left his hometown Nakatsu to find other viable development paths. Finally, in March 1855, he got his wish to enter the "Private school" opened by the Dutchman Hiroaki Ogata, and began his formal study of "Rangaku". From the 18 th to the 19th century, Japan had once set off an upsurge of learning Dutch language. The Japanese wanted to use language as a medium to better learn Western science and technology. Later, they classified the Western academic knowledge that introduced to Japan from the Netherlands during the period of the country's lock-up period as Rangaku. [1] It can also be said that Rangaku is the modern science of the western bourgeoisie. In the private school, Fukuzawa began to extensively absorb the concept of Rangaku and learn from others. Through systematic study, his knowledge reserves have been further expanded and he has begun to emerge. Since then, he began his travel lectures extensively.

Since the Black Ship incident, Japan's sense of crisis has continued to deepen, and this has also made the Meiji government eager to learn about the situation at home and abroad and introduce advanced Western science and technology in order to achieve the goal of consolidating politics and strengthening the country. As a result, Japan started a large-scale study abroad and overseas inspection activities. In 1860, he travelled to the United States as a warship attache. This was his first time traveling overseas. In 1862 and 1867, he went to Europe and the United States twice to conduct inspections. These experiences undoubtedly had a tremendous impact on his entire life and the composition of his ideology. [2] When he personally experienced various things in the Western world, his vision became more open, and he deeply felt that Japan's status in the international community was so low that the Oriental civilization he once proud of 
appeared so dwarfed compared with the advanced Western civilization, which led him to deep reflection. Fukuzawa's experience in the West also became a strong support and theoretical basis for his future thoughts.

\section{B. Overview of Fukuzawa's "Civilization Concept"}

The "Summary of Civilization Theory" is one of Fukuzawa's influential works worldwide. In this book, he explains how he defined "civilization." Today, there are many concepts for defining the concept of civilization, and in the book "Summary of Civilization Theory", Fukuzawa has summarized civilization as "people's peace and spiritual progress", and can also be said as "the progress of humanity's wisdom ".[3] A detailed analysis of the book shows that the term "civilization" described by Fukuzawa covers a wide range of topics, technology, system, literature, thought, wisdom, and even all the material and spiritual things in the human and social world are counted by him into the category of civilization, but of which he particularly advocate morality and mentality, he believed that people's moral and mental standards are an important measure of the development of a country's civilization. Therefore, Fukuzawa's civilization concept has a strong "evolution" ideology. He believes that civilization did not exist at the beginning, but it took a long process from barbarism to civilization and divided human society into "barbarous", "Semi-civilization", "Civilization" these three development stages, and it is also the famous "Syllogism of civilization" concept proposed by himself. [4]

The formation of the civilization concept of Fukuzawa was inseparable from Japan's social environment and the urgent international situation at that time. When the Western countries have basically completed social changes, social style is completely new, and national power is strength rapidly, his motherland Japan has just woken up in the gunfire of "black ship". Compared with the West, Japan has low productivity and lack of practical science; Japanese people have always been unable to get rid of decadent feudal superstitions. This social condition has given him a great sense of crisis. The more he looks at the status quo in Japan, the more he feels anxious and uneasy. Therefore, he hopes that Japan's civilization could be aligned with the West as soon as possible, and then considers transcending the West and further toward to the goal of advanced civilization. In the "New People's Situation", he discussed in detail the Eastern and Western civilizations, and he highlighted the prominent roles played by many advanced factors such as telecommunications, postal services, and steam transportation, and he called on people to rise and catch up with Europe and the United States. It should be noted that at that time, the Meiji government had the idea to cultivate talent with "Japan soul and Western skill", that is, to encourage its own citizens to learn the West, and at the same time also require them to retain Japan's traditional cultural practices. [5] However, Fukuzawa did not agree with this view. In his opinion, the Japan morality preserved in the idea of "Japan soul and Western skill" is still lagging behind in its nature, Japan should adopt radical innovations in both material civilization and spiritual civilization, that is, they should temporarily biased toward "Western soul and Western skill". Fukuzawa's understanding of civilization is quite forward- looking, he knows that although Western civilization is advanced, it still does not reach the final stage of civilization development, so what he advocated is not Westernization of the whole, but the short-term reference and absorption of Western civilization. After Fukuzawa's unremitting efforts, "Civilization and Enlightenment" was finally established as a national policy by the Japanese government. From the sentence "Seek knowledge from the world" in the "Five affidavits", we can also feel the aspiration of this pioneer for the innovation of civilization.

\section{C. "Civilization Concept" and "Asian Concept"}

In 1885, the "Current News" established by Fukuzawa published an article titled "Datsu-A Ron" in which he proposed new views on the Eastern countries headed by China, while criticizing the Eastern counties is anachronism and make no attempt to make progress, he advocates that Japan's social innovation has achieved tremendous development results and should team with the West in order to establish Asia's dominant position. This argument shocked Japan's inherent Asian concept centered on China and caused a great sensation in Japan and abroad. [6] In the article "Datsu-A Ron", Fukuzawa cited common problems in other countries in Asia, such as "make no attempt to make progress", "addict themselves to the old customs", "servility and have no sense of shame" and so on. Between the lines it fully filled with his disappointment to these countries' civilizations.

Fukuzawa uses the level of civilization as a criterion for judging whether a country is advanced or not. At the end of his "Datsu-A Ron", he came to the conclusion of "eclined the East Asia's evil friends". [7] This conclusion was obtained after a long time analysis of Japan's neighboring countries. At that time, most of the countries in the East were in a stagnant social state, and this caused a very bad influence on Japan. Therefore, in this context, the civilization evolution view in Fukuzawa's civilization concept led him to decide to advance and retreat with more advanced Western civilization. And in his opinion, Japan, with its own strength and advanced civilization, should be the leader of Asia with no doubt, and other countries in Asia, because of their low level of development and civilization, should be regarded as the dominated role. It is the Asian concept that he has established with a strong colonialism. It can be said that Fukuzawa's civilization concept has created his Asian concept.

\section{INDEPENDENT COUNTRY, PURE LAND OF PRACTICAL LEARNING}

\section{A. Pursue "Independence"}

In Fukuzawa's book "Encourage of learning" there is a sentence: "The so-called independence means that one does not have the psychology to rely on others and controls oneself". [8] On a personal level, to achieve the independence of material and spiritual, from the country and national perspective, a scientific and democratic country and a nation that stands in the forest of the world need an independent spirit. His civilization concept is based on the comparison between Japanese and Western civilizations, therefore he is well aware the realization of a civilized country requires independence as 
a prerequisite. When the people have independent thoughts and personalities, the new academic environment will have a stable development environment, and the Japanese society's atmosphere of emphasis on power will also be improved. Regarding independence, he does not only stay at the level of conception, he has also been practicing this idea. In the "Summary of Civilization Theory", he mentioned that "a country where everyone wants to be an official can't go to civilization", so naturally he never holds any senior government position, apart from this, we can also read Fukuzawa's independent politics from a place, at the beginning, Fukuzawa was skeptical about the reformists and was rather biased toward the shogunate. Later in the wave of "Repel the barbarians" and "Anti-intellectualism", he stood in the queue of new government and reformists. He has always taken independent actions to judge right and wrong from various angles, that is, he independently decides his own political actions and does not blindly rely on anyone. In all levels of independence mentioned by Fukuzawa Yukichi, he valued education the most and he clearly realized that if academic and political relations are linked, academic purity will be affected, so he proposed the theory of "Separation of academic and politics", and develop "independent education". He independently founded newspaper and private school, and conducted document translation work. As a nation of Japan, he performed his social responsibility well; as a famous scholar, he guided people to think and question, so that everyone had an independent heart and then created conditions for a civilized national system. It can be said that his understanding of the concept of "independence" is very profound.

\section{B. Focus on "Practical Learning"}

The so-called "practical learning", as its name suggests, is naturally opposed to "unpractical", both are measured by practicality. Looking at the background of the era at that time, in the 18th and 19th centuries Western society could use the word "practical" as a feature. As a product of industrial civilization, new industries such as the petrochemical industry have created enormous new economic and social benefits, energy sciences and other emerging disciplines have delivered a lot of practical talents to the society. Fukuzawa's practical thought have largely borrowed from the achievements of Western ideas and refined and improved them. His practical thought is based on the "empirical scientific spirit". This "practical learning" is opposed to the Japanese Confucianism who advocated the ruling order, so it has the significance of modern science.[9] "Independence" has two levels: material independence and spiritual independence, knowledge also has tangible and intangible distinctions, like disciplines such as chemistry and physics, they emphasize application and are tangible. Psychology, theology, and other disciplines emphasize the theoretical research and are intangible. However, impractical and intangible knowledge are two concepts that are not related. Intangible learning also belongs to the category of modern scientific spirit. The impractical knowledge he refers to is Confucianism who pursues moral centralism, and the stage goal of his practical learning is to eliminate impractical learning. Fukuzawa closely linked the concept of practical education with the Japanese society at that time and pointed out the direction of development for society. It played a very good guiding role.

Keio (now Keio University) is the embodiment and continuation of Fukuzawa's practical learning thought. Its predecessor is the "Lan Xue Shu" which was established by him in 1858, was only a small private school that transmitted Western natural sciences. Today, it has become the oldest private university in Japan's history; "Advocating practical learning and pursuing independence" is the mission of Keio. As the founder, Fukuzawa has been active in the front-line of school management, many foreign teachers and foreign language textbooks have been introduced into Keio. The school adheres to the principle of nature and extensively establishes practical disciplines such as commercial law, astronomy and so on. It places great emphasis on the practical application. Fukuzawa Yukichi believes that the development of the people's wisdom requires practical learning as a prerequisite, and practical learning is also a means of pursuing civilization. This education concept is reflected in his education career, since he established the school, it has maintained a good style of study, and always takes the realism as its principle. Now, 400 years have passed, and Fukuzawa's rhetoric words of "Japan would exists as a civilized country in the world as long as this school still exists" is still loud; and Keio also inherited Fukuzawa's academic spirit, walking towards a bright future.[10] Fukuzawa promoted practical learning in Japan, and history also proved that practical learning is an important driving force for Japan's prosperity and strength.

\section{CONCLUSION}

Someone once said:"Mankind has the right to the truth, and the fallacy belongs to the time". Fukuzawa Yukichi has analyzed the Eastern and Western civilization historically, he admires Western civilization, but he still regards it as a category of historical development. This is a rare and commendable, but his thoughts also have negative and compromised aspects, such like the extreme attitude to the "westernization" and the East Asian countries,on one side it is due to his own class limitations and on the other side it is because of the huge differences in the level of development between the East and West. In spite of this, there are still many places in his mind worth digging, and history has also confirmed that his thought has played a huge role in promoting the modernization of Japanese society. "Civilization", "Independence" and "Practical learning" are issues that run through the times. Compared to a century ago, today's society has undoubtedly reached a high degree of civilization. However, the problems related to civilization have continued to emerge, science and technology has nurtured new civilizations, but it has caused a impact to traditional civilization, globalization has intensified the civilization impact, while the problems of academic hollowing and the independence of the country and the individual are still outstanding. Fukuzawa's thoughts can provide us with many references, we should learn from the essence of his thoughts to find solutions to these problems which meet the requirements of the times. 


\section{REFERENCES}

[1] [JP] Fukuzawa Yukichi. "Fukuzawa Yukichi's autobiography" [M]. Translated by Ma Bin. Beijing: Commercial Press, 1980. 180-182.

[2] Wang Xuanyu. Research on Fukuzawa Yukichi's thought of "Datsu-A Ron” [D]. Jilin University 2016. 17-35.

[3] [JP] FukuzawaYukichi."Summary of Civilization Theory"[M]. Translated by Beijing Compiling Bureau. Beijing: Commercial Press, 1997. 30-50.

[4] [JP] Okamoto Koji. Asian concept of Modern Japan [M]. Kyoto: The Study Room, 1998.12-18.

[5] [JP]FukuzawaYukichi. "Encourage of learning" [M]. Translated by Qun Li. Beijing: Commercial Press, 1984.25-40.

[6] [JP] Shinji Kisaburo, Translated by Institute of Japan Studies of Tianjin Academy of Social Sciences. "Japanese Diplomacy History"[M]. Commercial Press, 1980.42-46.

[7] [JP] Yoshihiro Toyama. "Fukuzawa Yukichi - The connection between thought and politics" [M]. Tokyo: Tokyo University Press, 1985.13-22.

[8] Xu Yinyin. "Civilization, Independence, Practical Learning: A New Understanding of Fukuzawa Yukichi's Educational Thoughts" [D]. Nanjing University 2012.24-27.

[9] [JP] Shikano Masano, Translated by Bian Chongdao. "Fukuzawa Yukichi” [M]. SDX Joint Publishing Company, 1987.65-81.

[10] Keio University Official Website History Museum https://www.keio.ac.jp/en/ 